\title{
PENGEMBANGAN MEDIA PANLINTARMATIKA (PAPAN PERKALIAN PINTAR MATEMATIKA) MATERI PERKALIAN UNTUK SISWA SEKOLAH DASAR
}

\author{
Hasna Nur Afifah, Meita Fitrianawati * \\ ${ }^{*}$ Coresponding author
}

Universitas Ahmad Dahlan

Email: hasnafifah96@gmail.com

\begin{tabular}{|c|c|}
\hline Info Artikel & Abstract \\
\hline $\begin{array}{l}\text { Sejarah Artikel: } \\
\text { Diserahkan 22 Januari } 2021 \\
\text { Direvisi } 29 \text { April } 2021 \\
\text { Disetujui 03 Mei } 2021\end{array}$ & $\begin{array}{l}\text { This study aims to 1) find out the steps in developing Panlintarmatika learning media, 2) } \\
\text { know the feasibility of developing Panlintarmatika learning media based on experts. } \\
\text { This study is a type of Research and Development }(R \& D) \text { research using the Borg and Gal } \\
\text { model which consists of: (1) research and information collecting, (2) planning, (3) } \\
\text { developing preliminary from a product, (4) prelimunary field testing, (5) main product }\end{array}$ \\
\hline $\begin{array}{l}\text { Keywords: } \\
\text { Learning media, } \\
\text { Panlintarmatika, mathematics, } \\
\text { elementary school, }\end{array}$ & $\begin{array}{l}\text { revision, (6) main field testing, (7) operational product revision (8) operational field testing. } \\
\text { The trial subjects used were } 18 \text { grade } 2 \text { students and teachers at SD N Kalangan. Data } \\
\text { collection techniques in the form of observation, interviews and questionnaires. Data } \\
\text { analysis includes quantitative data analysis and qualitative data analysis. } \\
\text { The results showed that the validation of the media experts received a score of } 60 \text { in the } \\
\text { "Very good" category, the validation of the material experts received a score of } 42 \text { in the } \\
\text { "Good" category and the learning expert received a score of } 60 \text { in the "Good" category. The } \\
\text { results of the small-scale field test students get a score of } 100 \text { with the category "Very Good" } \\
\text { and the teacher gets a score of } 94 \text { with the category "Very Good". Large-scale field test } \\
\text { results students get a score of } 100 \text { with the category "Very Good" and the teacher scores } 98 \\
\text { with a score of "Very Good" It can be concluded that the Panlintarmatika learning media is } \\
\text { feasible and can be used as class } 2 \text { learning multiplication material }\end{array}$ \\
\hline
\end{tabular}

\begin{abstract}
Abstrak
Penelitian ini bertujuan untuk 1) mengetahui langkah-langkah pengembangan media pembelajaran Panlintarmatika, 2) mengetahui kelayakan pengembangan media pembelajaran Panlintarmatika berdasar para ahli.

Penelitian ini termasuk jenis penelitian Research and Development (R\&D) dengan menggunakan model Borg and Gall yang terdiri dari: (1) research and information collecting, (2) planning, (3) develop preliminary from a product, (4) prelimunary field testing, (5) main product revision, (6) main field testing, (7) operational product revision (8) operasional field testing. Subyek uji coba yang digunakan adalah 18 siswa kelas 2 dan guru di SD N Kalangan. Teknik pengumpulan data berupa observasi, wawancara dan angket. Analisis data melipu ti analisis data kuantitatif dan analisis data kualitatif.

Hasil penelitian menunjukkan validasi dari ahli media mendapatkan skor 60 dengan kategori "Sangat baik", validasi ahli materi mendapatkan skor 42 dengan kategori "Baik" dan ahli pembelajaran mendapatkan skor 60 dengan kategori "Baik". Hasil uji lapangan skala kecil siswa mendapatkan skor 100 dengan kategori "Sangat Baik" dan guru mendapatkan skor 94 dengan kategori "Sangat Baik". Hasil uji lapangan skala besar siswa mendapatkan skor 100 dengan kategori "Sangat Baik" dan guru mendapatkan skor 98 dengan skor "Sangat Baik" Dapat disimpulkan bahwa media pembelajaran Panlintarmatika layak dan dapat digunakan sebagai pembelajaran kelas 2 materi perkalian.
\end{abstract}




\section{Hasna Nur Afifah dan Meita Fitrianawati \\ PENGEMBANGAN MEDIA PANLINTARMATIKA (PAPAN PERKALIAN PNTAR ... WASIS: Jurnal Ilmiah Pendidikan. Volume 2 Nomor 1, Mei 2021, hlm. 41-47}

\section{PENDAHULUAN}

Pembelajaran matematika merupakan mata pelajaran umum yang terdapat pada jenjang Sekolah Dasar sampai dengan Perguruan Tinggi. Pembelajaran matematika adalah salah satu mata pelajaran yang ada di lingkup Sekolah Dasar. Mata pelajaran matematika diberikan kepada siswa mulai dari tingkat SD untuk membekali mereka dalam memiliki kemampuan berpikir logis, analitis, sistematis, kritis dan kreatif, serta kemampuan bekerjasama (Saputro, 2018). Menurut Sundayana (2016) matematika merupakan salah satu komponen dari serangkaian mata pelajaran yang mempunyai peranan penting dalam pendidikan.

Pembelajaran yang menjadi sorotan masyarakat saat ini adalah mata pelajaran matematika (Fitrianawati, 2011). Salah satu materi pembelajaran matematika adalah materi perkalian. Heruman (2012) menyatakan perkalian termasuk topik yang sangat sulit untuk dipahami sebagian siswa. Guru harus menggunakan berbagai cara untuk mengajarkan materi perkalian ke siswa agar mudah dipahami. Operasi hitung perkalian merupakan materi yang harus dipahami oleh siswa yang nantinya dalam operasi perkalian dapat diterapkan dalam kehidupan sehari-hari.

Siswa Sekolah Dasar (SD) umumnya berkisaran antara 6 atau 7 tahun, sampai 12 atau 13 tahun. Menurut Piaget (Heruman, 2012)., dalam mereka berada pada fase operasional konkret. Kemampuan yang tampak pada fase ini adalah kemampuan dalam proses berfikir untuk mengoperasikan kaidah-kaidah logika, meskipun terikat pada objek yang bersifat konkret. Dari usia perkembangan kongnitif, siswa SD masih terkait dengan objek konkret yang dapat ditangkap oleh panca indera. Dalam pembelajaran matematika yang abstrak, siswa memerlukan alat bantu berupa media, dan alat peraga yang dapat memperjelas apa yang akan disampaikan oleh guru sehingga lebih cepat dipahami dan dimengerti oleh siswa.

Media pembelajaran sangat berperan penting dalam meningkatkan kualitas pendidikan, termasuk untuk peningkatan kualitas pendidikan matematika (Dewi dan Yuliana, 2018). Media pendidikan dapat dipergunakan untuk membangun pemahaman dan penguasaan objek pendidikan (Sundayana, 2016). Daryanto (2016) mengatakan media merupakan salah satu komponen komunikasi yaitu pembawa pesan dari komunikator menuju komuikan. Jadi, dengan menggunakan media pembelajaran akan ada interaksi antara guru dengan siswa dengan menggunakan alat bantu berupa media pembelajaran. Pembelajaran akan membosankan ketika guru tidak menggunakan media dalam proses pembelajaran (Nugraheni, 2017). Hal ini disebabkan karena karakteristik anak kelas rendah masih pada tahap operasional konkrit. Menurut Ulfah (2013) belajar menggunakan media bisa meningkatkan motivasi belajar siswa.

Dari hasil observasi di SD N Kalangan, siswa mengalami kesulitan dalam mata pelajaran matematika. Materi yang dirasa sulit oleh siswa yaitu materi perkalian. Guru hanya sekedar ceramah dalam menyampaikan materi sehingga siswa menjadi kurang tertarik dalam pembelajaran dan tidak fokus pada pembelajaran mereka lebih asik dengan dunianya sendir.

Berdasarkan hasil wawancara dengan guru kelas 2 di SD N Kalangan pada tanggal 25 April 2019 menyatakan kurikulum yang digunakan di SD tersebut adalah kurikulum 2013. Permasalahan yang dihadapi oleh uguru adalah yang pertama terkait dengan materi yang sulit dikuasai oleh siswa pada mata pelajaran matematika, diperoleh bahwa sejauh ini materi yang masih sulit dipahami oleh siswa adalah pada materi perkalian. Dalam hal ini siswa masih mengalami kesulitan untuk mengoperasi perkalian. Kedua, banyak siswa yang tidak terlibat aktif dalam proses pembelajaran sehingga siswa belum sepenuhnya dalam menguasai pembelajaran matematika khusunya materi perkalian. Ketiga, terbatasnya penggunaan media pembelajaran matematika yang menarik bagi siswa untuk mempelajari materi perkalian. Dalam proses pembelajaran guru masih menggunakan buku paket saja dan belum menggunakan media pembelajaran sehingga proses pembelajaran tampak membosankan dan siswa kurang memperhatikan materi yang disampaikan.

Salah satu media pembelajaran untuk mengatasi permasalahan belajar matematika pada materi perkalian adalah media pembelajaran Papan Perkalian Pintar Matematika (Panlintarmatika). Alasan peneliti menggunakan media ini di kelas rendah, yaitu menjadikan siswa memahami perkalian sejak duduk di kelas rendah, baik memahami dari segi konsep maupun cara menghitung yang benar. Menurut Sintawati (2017), hal yang mendasar dan penting dalam matematika adalah kemampuan dalam memahami konsep.

Tujuan penelitian ini adalah untuk 1) mengetahui langkah-langkah pengembangan media pembelajaran Panlintarmatika, 2) mengetahui kelayakan pengembangan media pembelajaran Panlintarmatika berdasarkan ahli.

\section{METODE PENELITIAN}

Penelitian ini menggunakan metode penelitian dan pengembangan atau disebut juga 
dengan istilah Research and Development (R\&D). Dalam penelitian pengembangan media Papan Perkalian Pintar Matematika, langkahlangkah yang digunakan adalah model pengembangan Brog and Gall dengan melakukan delapan dari sepuluh prosedur pengembangan sebagai berikut: (1) Research and Information Collecting (penelitan dan pengumpulan data), (2) Planning (perencanaan), (3) Delevop Preliminary Forn a Product (mengembangkan produk awal), (4) Preliminary Field Testing (uji lapangan awal), (5) Main Product Revision (revisi produk), (6) Main Field Testing (uji coba lapangan), (7) Operational Product Revision (revisi produk), (8) Operasional Field Testing (uji coba lapangan) (Borg \& Gall, 1989).

Instrumen pengumpulan data pada penelitian ini adalah observasi, wawancara dan kuisioner (angket). Observasi dan wawancara dilakukan di awal untuk menemukan permasalahan yang ada pada pembelajaran matematika pada materi perkalian kelas 2 . Pengumpulan data berupa angket digunakan karena jumlah respoden cukup banyak. Lembar angket ditujukan kepada para ahli (ahli media, ahli materi dan ahli pembelajaran) untuk menilai kualitas media dan lembar angket ditujukan kepada siswa, untuk mengetahui kelayakan media berdasarkan respon siswa dan guru.

Teknik analisis data digunakan untuk mengolah data yang didapatkan dari lembar angket. Analisis data dalam penelitian ini adalah analisis data kuantitatif dan analisis data kualitatif. Data kuantitatif didapatkan dari penilaian lembar validasi para ahli dan lembar respon siswa dan guru. Penilaian dari lembar validasi para ahli dan guru berpedoman pada penggunaan skala Likert (Widoyoko, 2013).

Tabel 1. Pedoman Penilaian Skala Likert

\begin{tabular}{cc}
\hline Kategori & Skor Penilaian \\
\hline Sangat Baik & 5 \\
Baik & 4 \\
Cukup & 3 \\
Kurang & 2 \\
Sangat Kurang & 1 \\
\hline
\end{tabular}

Untuk menganalisis data penilaian skor dari siswa dalam bentuk ceklist menggunakan skala Guttman. Skala pengukuran tipe Guttman didapat jawaban yang tegas, yaitu "ya-tidak"; "benar-salah"; "pernah-tidak"; "positif-negatif" dan lain-lain (Sugiono, 2018).

Tabel 2. Pedoman Penilaian Skala Guttman

\begin{tabular}{lc}
\hline Kategori & Skor Penilaian \\
\hline Ya (Setuju) & 1 \\
Tidak (Tidak Setuju) & 0 \\
\hline
\end{tabular}

Penilaian lembar validasi oleh para ahli dan respon siswa dan guru yang telah dinilai berdasarkan pedoman penilaian skala Likert dan skala Guttman selanjutnya dihitung utuk mendapatkan jumlah skor. Skor nilai dikonversikan menjadi lima kriteria dengan menggunakan Skala Likert. Kriteria dapat dilihat pada Tabel 3 berikut.

Tabel 3. Kriteria Penilaian

\begin{tabular}{lc}
\hline \multicolumn{1}{c}{ Rentang Skor } & Kriteria \\
\hline $\mathrm{X}>\overline{x i}_{+} 1,8 \mathrm{Sbi}$ & Sangat Baik \\
$\mathrm{Mi}+0, \mathbf{6 0} \mathrm{Sbi}<\mathrm{X}<\mathrm{Mi}+1,8 . \mathrm{Sbi}$ & Baik \\
$\mathrm{Mi}-0,60 \mathrm{Sbi}<\mathrm{X} \leq \mathrm{Mi}+0,6 . \mathrm{Sbi}$ & Cukup \\
$\mathrm{Mi}-1,8 \mathrm{Sbi}<\mathrm{X} \leq \mathrm{Mi}-0,6 . \mathrm{Sbi}$ & Kurang \\
$\mathrm{X} \leq \mathrm{Mi}-1,8 \mathrm{Sbi}$ & Sangat Kurang \\
\hline
\end{tabular}

Keterangan:

$\mathrm{X}=$ skor aktual

$\mathrm{Mi} \quad=$ mean ideal

Sbi $\quad=$ simpangan baku ideal

Data kualitatif didapatkan dari hasil wawacara di awal penelitian dan dari saran atau komentar dari para ahi, siswa dan guru yang tertulis berdasarkan lembar validasi dan lembar respon siswa. Data yang diperoleh dianalisis dan dideskripsikan secara kualitatif untuk merevisi produk yang dikembangkan. Penelitian pengembangan media pembelajaran Papan Perkalian Pintar Matematika dinyatakan layak digunakan apabila skor yang didapatkan termasuk dalam kategori "Baik".

\section{HASIL DAN PEMBAHASAN}

Hasil pengembangan yang telah dilakukan oleh peneliti dalam penelitian dan pengembangan media pembelajaran Papan Perkalian Pintar Matematika pada materi perkalian kelas 2 Sekolah Dasar dipaparkan dalam langkah-langkah berikut.

\section{Research and Information Collecting (Pengumpulan Data)}

Tahap awal penelitian yang dilakukan adalah mengumpulkan informasi dengan melakukan observasi, wawancara dan menganalisis kebutuhan. Berdasarkan hasil observasi dan wawancara bahwa guru sudah menggunakan media pembelajaran dalam proses belajar mengajar tetapi yang digunakan guru yaitu media pembelajaran buku paket. Oleh karena itu, siswa kurang aktif, kurang antusias karena pembelajaran hanya berpusat pada guru. Ketertarikan siswa dalam belajar khususnya pada mata pelajaran matematika masih kurang. Hal ini dibuktikan saat proses pembelajaran matematika berlangsung sebagian siswa kurang 
memperhatikan apa yang dijelaskan oleh guru. Siswa lebih tertarik berbicara atau bermain dengan teman sebangkunya. Hal tersebut dapat terjadi karena guru belum menggunakan media pembelajaran dalam kegiatan pembelajaran. Sejalan dengan pendapat Ardianti, dkk (2019) bahwa penggunaan media pembelajaran dalam kegiatan belajar dapat meningkatkan ketertarikan siswa dalam belajar.

\section{Planning (Perencanaan)}

Pada tahap planning terdiri dari, mendefinisikan keterampilan, dan merumuskan tujuan. Papan Perkalian Pintar Matematika (Panlintarmatika) bertujuan untuk membantu proses pembelajaran yang dapat digunakan atau dipraktekan langsung oleh siswa. Media pembelajaran ini berisi mengenai mata pelajaran matematika dengan isi materi perkalian.

\section{Develop Preliminary Form a Product (Mengembangkan Produk Awal)}

Pada tahap ini penulis mulai merancang dan membuat media pembelajaran. Tahap-tahap membuat media pembelajaran Papan Perkalian Pintar Matematika (Panlintarmatika) yaitu: 1) menentukan Kompetensi Inti (KI), Kompetensi Dasar (KD) dan Indikator, 2) menentukan desain media pembelajaran, 3) menggambar desain media pembelajaran, 4) menentukan bahan-bahan pembuatan media pembelajaran, 5) membuat media pembelajaran Papan Perkalian Pintar Matematika (Panlintarmatika).

Preliminary Field Testing (Uji Lapangan Awal)

Uji lapangan awal dilakukan setelah mengembangkan produk awal. Uji lapangan awal dilakukan dengan cara memvalidasi media yang dilakukan oleh ahli media, ahli materi, dan ahli pembelajaran menggunakan lembar angket untuk mendapatkan penilaian tentang kelayakan media pembelajaran Papan Perkalian Pintar Matematika (Panlintarmatika). Rekapitulasi hasil penilaian dari ahli media, ahli materi, dan ahli pembelajaran disajikan dalam Tabel 4 berikut ini.

Tabel 4. Rekapitulasi Hasil Validasi Ahli

\begin{tabular}{ccc}
\hline Ahli & Skor Penilaian & Kategori \\
\hline Media & 60 & Sangat Baik \\
Materi & 42 & Baik \\
Pembelajaran & 60 & Baik \\
\hline
\end{tabular}

Berdasarkan Tabel 4 diketahui bahwa penilaian ahli menunjukkan bahwa media yang dikembangkan layak digunakan sebagai media pembelajaran perkalian untuk kelas 2 SD.

\section{Produk Revision (Revisi Produk)}

Revisi produk dilakukan setelah mendapatkan penilaian dan saran dari para ahli untuk dapat melangkah ke tahap selanjutnya.
Revisi produk dilakukan dengan memperbaiki media pembelajaran sesuai dengan penilaian dan saran dari ahli.

Main Field Testing (Uji Coba Lapangan)

Uji coba lapangan skala kecil dilakukan pada kelas 2 SD $\mathrm{N}$ Kalangan setelah proses validasi dan revisi selesai. Media pembelajaran Papan Perkalian Pintar Matematika (Panlintarmatika) diuji cobaka kepada 4 siswa dan guru kelas 2. Rata-rata hasil dari lembar respon siswa menunjukan nilai 100 dengan kategori "Sangat Baik". Sedangkan respon guru mendapatkan skor nilai 94 dengan kategori "Sangat Baik" dan mendapatkan saran perbaikan untuk media pembelajaran.

Operational Product Revision (Revisi Produk)

Tahap selanjutnya setelah uji coba lapangan skala kecil adalah revisi produk berdasarkan saran dari siswa dan guru pada uji coba skala kecil untuk memperbaiki media pembelajaran Papan Perkalian Pintar Matematika (Panlintarmatika).

\section{Operasional Field Testing (Uji Coba Lapangan)}

Setelah dilakukan revisi produk berdasarkan saran yang diberikan, tahap selanjutnya adalah uji coba lapangan besar pada 18 siswa dan guru kelas 2 SD N Kalangan. Hasil dari lembar respon 18 siswa kelas 2 terhadap media pembelajaran Papan Perkalian Pintar Matematika (Panlintarmatika) mendapatkan nilai 100 dengan kategori "Sangat Baik". Sedangkan respon guru mendapatkan skor nilai 98 dengan kategori "Sangat Baik".

Data uji coba pada penelitian pengembangan media pembelajaran Papan Perkalian Pintar Matematika (Panlintarmatika) pada materi perkalian menggunakan data kuantitatif dan kualitatif. Data kuantitatif digunakan untuk mencari nilai dari penilaian validasi ahli media, ahli materi dan ahli pembelajaran serta mencari nilai dari penilaian respon siswa dan guru di SD N Kalangan melalui uji coba lapangan skala kecil dan uji coba lapangan skala besar. Tabel 5 adalah data kuantitatif hasil dari penilaian validasi para ahli dan penilaian respon siswa dan guru.

Tabel 5. Data Kuantitatif Hasil Penilaian terhadap Media

\begin{tabular}{clcc}
\hline No & \multicolumn{1}{c}{ Penilaian } & Nilai & Kategori \\
\hline 1. & Ahli Media & 60 & Sangat Baik \\
2. & Ahli Materi & 42 & Baik \\
3. & Ahli Pembelajaran & 60 & Baik \\
4. & Respon Guru & 96 & Sangat Baik \\
5. & Respon Siswa & 100 & Sangat Baik \\
\hline
\end{tabular}


Data kualitatif didapatkan dari hasil wawancara dan pemberian saran oleh para ahli dalam lembar validasi dan lembar respon siswa dan guru. Saran dari ahli media, ahli materi dan ahli pembelajaran digunakan untuk memperbaiki media pembelajaran sebelum digunakan untuk uji coba lapangan. Setelah media pembelajaran direvisi, media pembelajaran digunakan untuk uji coba lapangan di SD N Kalangan. Dalam uji coba lapangan siswa dan guru memberikan saran untuk perbaikan media pembelajaran. Berikut ini adalah data kualitatif berdasarkan saran dari para ahli, siswa dan guru terhadap media pembelajaran Papan Perkalian Pintar Matematika

1. Analisis Data Ahli Media

Ahli media memberikan saran untuk memperbaiki media pembelajaran Papan Perkalian Pintar Matematika yaitu warna media kurang menarik, isi dalam setiap halaman dan cara penggunaann media pembelajaran. Hal tersebut sesuai dengan pendapat Ardianti dan Ristiyani (2017) bahwa penggunaan warna cerah dapat menambah daya tarik dari sebuah media pembelajaran/

2. Analisis Data Ahli Materi

Ahli materi memberikan kritik dan saran untuk memperbaiki media pembelajaran Papan Perkalian Pintar Matematika tersebut diantaranya ukuran font, jenis font, tata letak kolom perkalian dan judul.

3. Analisis Data Ahli Pembelajaran

Ahli pembelajaran memberikan kritik dan saran untuk memperbaiki media pembelajaran Papan Perkalian Pintar Matematika adalah warna media kurang menarik.

4. Analisis Data Uji Coba Skala Kecil

Pemberian respon pada uji coba skala kecil dilakukan oleh empat siswa dan guru. Adapun saran untuk media pembelajaran Papan Perkalian Pintar Matematika adalah warna yang digunakan kurang menarik.

5. Analisis Data Uji Coba Skala Besar

Pemberian respon pada uji coba skala besar dilakukan oleh 18 siswa dan guru. Pada uji coba skala besar tidak ada saran perbaikan dari siswa ataupun guru. Kesimpulan dari seluruh saran siswa adalah media pembelajaran Papan Perkalian Pintar Matematika sudah menarik dan mudah dipahami untuk mempelajari materi perkalian.

Produk akhir dari media pembelajaran Papan Perkalian Pintar Matematika adalah media yang telah divalidasi oleh ahli media, ahli materi dan ahli pembelajaran dengan melalui proses revisi. Hasil produk akhir peelitian dan pengembangan ini adalah media pembelajaran Papan Perkalian Pintar Matematika yang termasuk ke jenis media visual. Wati (2016) menyatakan media visual merupakan sebuah media yang dimiliki beberapa unsur berupa garis, bentuk, warna, dan tekstur dalam penyajiannya.

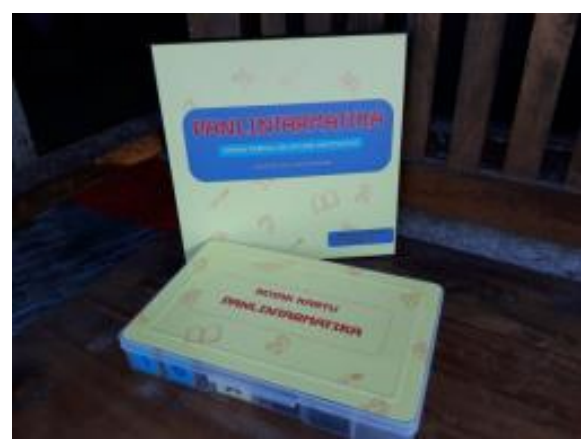

Gambar 1. Media Pembelajaran Panlintarmatika

Media pembelajaran Papan Perkalian Pintar Matematika ini berbentuk persegi dengan ukuran $60 \mathrm{~cm}$ x $60 \mathrm{~cm}$. Media tersebut berbahan dasar kayu dengan warna latar kuning. Media pembelajaran ini mempunyai 4 bagian. Bagian pertama atau depan terdapat judul media pembelajaran, bagian kedua terdapat penggunaan media pembelajaran, bagian ketiga terdapat sinopsis media pembelajaran dan bagian keempat terdapat nama pengembang dan nama dosen. Jika empat bagian tersebut dibuka semua, maka terdapat papan perkalian 1-10. Media pembelajaran ini dilengkapi dengan kartu butiran, kartu angka soal dan kartu angka jawaban. Media pembelajaran ini dapat digunakan untuk mengatasi keterbatasan media pada pembelajaran matematika materi perkalian kelas 2 .

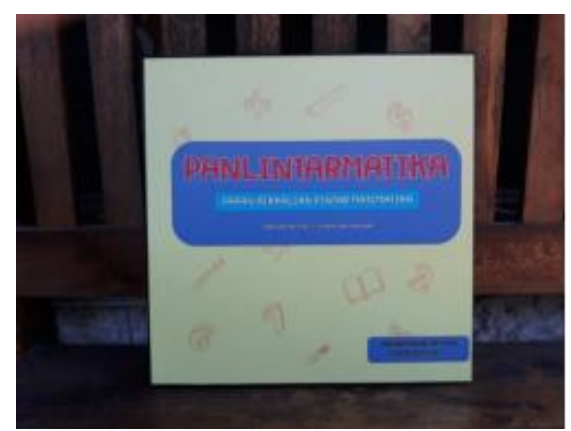

Gambar 2. Bagian Depan Media

Gambar tersebut adalah tampilan bagian depan cover media pembelajaran. Media pembelajaran ini dilengkapi dengan stiker dan gambar yang mendukung media pembelajaran tersebut seperti gambar penggaris, penghapus, pensil dan angka-angka. Selain itu cover juga dilengkapi dengan nama media pembelajaran dengan warna merah, kepanjangan media pembelajaran diberi warna putih dan untuk kelas 2 diberi warna putih dengan diblok warna biru 
agar bisa dibaca jelas oleh siswa. Selain itu, bagian pojok kanan diberi nama dan NIM pengembang.

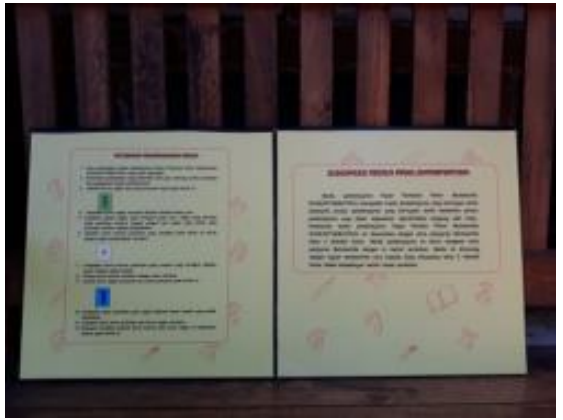

Gambar 3. Bagian Kedua dan Ketiga Media

Gambar tersebut merupakan bagian kedua dan ketiga media pembelajaran. Jika dibuka menjadi dua bagian, bagian kiri merupakan petunjuk penggunaan media pembelajaran dan bagian kanan merupakan biografi media pembelajaran. Judul petunjuk penggunaan media pembelajaran dan judul biografi media pembelajaran diberi warna merah dan jenis font Comic Sans.

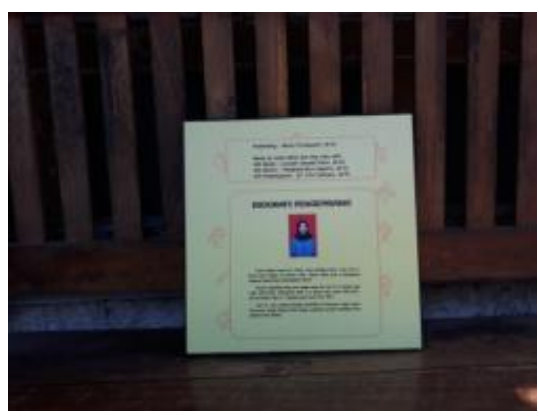

Gambar 4. Bagian Keempat Media

Gambar tersebut merupakan bagian belakang media pembelajaran yang terdapat nama dosen pembimbing, dosen validasi ahli, dan biografi pengembang.

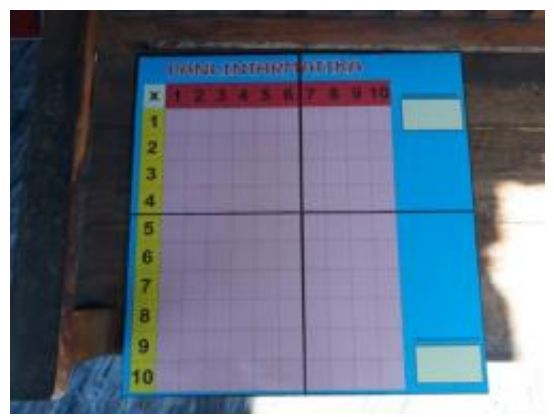

Gambar 5. Bagian Utama Media

Gambar tersebut merupakan bagian dalam papan perkalian, jika dibuka menjadi empat bagian. Bagian atas papan perkalian diberi judul nama media pembelajaran dengan warna merah. Papan perkalian terdiri dari angka 1 - 10. Angka 1 - 10 mendatar diberi warna merah dan angka 1 - 10 menurun diberi warna kuning. Kolom perkalian terdiri dari 100 kolom. Bagian kanan atas terdapat kolom untuk menempelkan soal dan bagian kanan bawah terdapat kolom untuk menjawab soal perkalian tersebut dengan benar.

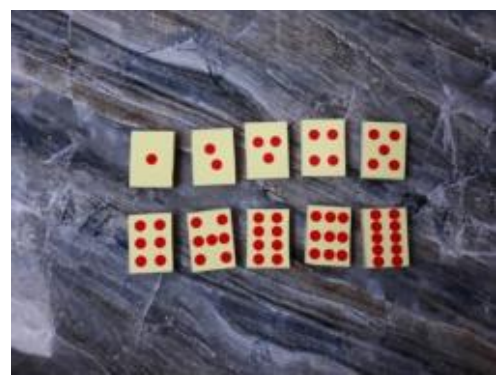

Gambar 6. Kartu Butiran

Gambar tersebut merupakan kartu butiran yang berfungsi untuk menghitung soal perkalian.
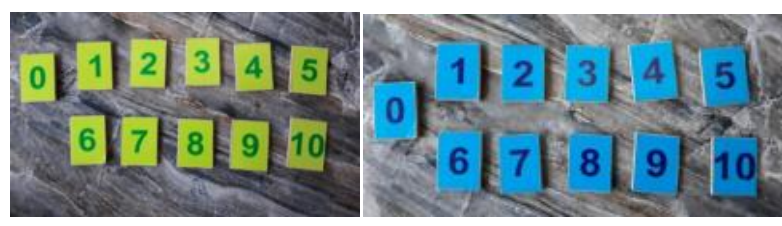

Gambar 6. Kartu Angka

Gambar tersebut merupakan kartu angka. Kartu angka terdiri dari dua warna yaitu warna hijau merupakan kartu angka soal dan warna biru merupakan kartu angka jawaban.

Berdasarkan nilai dari ahli media, ahli materi, ahli pembelajaran, siswa dan guru media pembelajaran Papan Perkalian Pintar Matematika menjadi produk akhir yang layak digunakan dalam proses belajar mengajar matematika pada materi perkalian kelas 2 Sekolah Dasar.

Berdasarkan hasil observasi yang telah dilakukan saat penelitian dilaksanakan antusias siswa dalam menggunakan media pembelajaran yang telah dikembangkan sangat baik terlihat siswa tidak sabar menggunakan media pembelajaran.

Pada saat proses pembelajaran siswa bisa terlibat langsung dalam pembelajaran, karena siswa bisa mengoperasikan media dengan sendiri. Media pembelajaran ini bisa digunakan secara individu maupun secara berkelompok. Siswa sangat antusias ketika penulis mendemontrasikan media pembelajaran. Cara penggunaan media pembelajaran sangat mudah karena dalam media pembelajaran sudah dilengkapi dengan petunjuk penggunaan media pembelajaran. 


\section{SIMPULAN}

Media pembelajaran Papan Perkalian Pintar Matematika pada materi perkalian dinyatakan layak digunakan berdasarkan penilaian kualitas ahli media, ahli materi dan ahli pembelajaran serta kelayakan media dari respon siswa dan guru. Produk akhir media pembelajaran Papan Perkalian Pintar Matematika (Panlintarmatika) merupakan media yang termasuk ke dalam jenis media visual.

\section{DAFTAR PUSTAKA}

Ardianti, S. D., Wanabuliandari, S., \& Rahardjo, S. 2019. The Implementation Of E-JAS Science Edutainment To Improve Elementary School Student's Conceptual Understanding. Unnes Science Education Journal, 8(1).

Ardianti, S. D., \& Ristiyani, R. (2017). Pemahaman Pendidikan Seks Usia Dini Melalui Modul Anggota Tubuh Manusia. JURNAL PENDIDIKAN SAINS (JPS), 5(2), 65-70.

Daryanto. 2016. Media Pembelajaran. Yogyakarta: Gava Media.

Dewi, T. K., \& Yuliana, R. (2018). Pengembangan Media Pembelajaran Scrapbook Materi Karangan Deskripsi Mata Pelajaran Bahasa Indonesia Kelas III Sekolah Dasar. Refleksi Edukatika: Jurnal Ilmiah Kependidikan, 9(1).

Fitrianawati, Meita. 2017. Penerapan Problem Based Learning (PBL) Dalam Meningkatkan Minat Belajar Matematika Pada Mahasiswa PGSD UAD Semester I TH. 2016/2017. JPSD Vol. 3, No 2, hlm. 14-23.

Gall, Meredith., Joyce P. Gall dan Walter R. Borg. 1989. Educational Research: An Introduction. USA: Pearson Education Inc.

Heruman. 2012. Model Pembelajaran Matematika. Bandung: Remaja Rosdakarya.

Nugraheni, N. 2017. Penerapan Media Komik Pada Pembelajaran Matematika Di Sekolah Dasar. Refleksi Edukatika : Jurnal Ilmiah Kependidikan, 7(2): 111-117.

Saputro, Hengkang Bara. 2018. Pengembangan Modul Matematika Dengan Pendekatan Konteksual Pada Materi Bangun Ruang Sisi Lengkung Untuk Mahasiswa PGSD UAD. JPSD, Vol. 5 No. 1, hlm.53-61
Sintawati, Mukti. 2017. Pengembangan Modul Berbasis Penemuan Terbimbing Pada Materi Bangun Ruang Sisi Datar Bagi Mahasiswa PGSD UAD. JPSD, Vol. 3, No. 2, hlm. 2433.

Sugiono. 2018. Metode Penelitian Kuantitatif, Kualitatif dan $R \& D$. Bandung: Alfabeta.

Sundayana, Rostina. 2016. Media dan Alat Peraga dalam Pembelajaran Matematika. Bandung: Alfabeta.

Ulfah, Amaliyah. 2013. Upaya Meningkatkan Kemampuan Berhitung Siswa Kelas III SD melalui Media Permaina "UTANG". DIDAKTIKA. Vol.1 No 1.

Wati, Ega Rima. 2016. Ragam Media Pembelajaran. Kota Pena. 